\title{
Geography Matters for Sanitation! Spatial Heterogeneity of the District-level Correlates of Open Defecation in India
}

\author{
Saurav Chakraborty ( $\nabla$ saurav.kgp1988@gmail.com ) \\ Presidency University Kolkata https://orcid.org/0000-0002-3317-0677 \\ Josef Novotný \\ Charles University, Prague \\ Jadab Das \\ Vidyasagar University \\ Aditi Bardahn \\ Presidency University Kolkata
}

\section{Srijanee Roy}

Presidency University Kolkata

\section{Swikriti Mondal}

Presidency University Kolkata

Priyank Pravin Patel

Presidency University Kolkata

\section{Sneha Santra}

Presidency University Kolkata

Indranil Maity

University of Calcutta

\section{Rimi Biswas}

Presidency University Kolkata

Aparajita Maji

Presidency University Kolkata

\section{Suvamoy Pramanik}

Jawaharlal Nehru University

\section{Research}

Keywords: environmental health, multi-scale geographically weighted regression, open defecation, India, spatial heterogeneity

Posted Date: June 30th, 2020

DOI: https://doi.org/10.21203/rs.3.rs-37223/v1

License: (c) (i) This work is licensed under a Creative Commons Attribution 4.0 International License. Read Full License 


\section{Abstract}

Background: Sanitation interventions often fail in meeting the desired expectations. A prominent reason is the ecological nature of sanitation phenomena that inherently associates with its high dependence on contextual specifics. This also constrains the generalization of research findings in this domain and substantiates the need to supplement most prevalent micro-level evidence with wider population-level (ecological) studies. This paper thus provides the first quantitative analysis of the spatial heterogeneity of the district-level correlates of open defecation in India. It focuses on a contiguous region of 266 districts (their rural parts) comprising of seven northern and eastern Indian states, all of which had comparatively high open defecation rates in 2011.

Methods: We employ standard non-spatial regression, spatially explicit regressions and multi-scale geographically weighted regression to compare the stability of the measurable correlates of open defecation across these different methods as well as across the analyzed spatial units.

Results: Attributes like the ownership of household assets, drinking water inaccessibility and prevalent literacy rates were identified as the most stable district-level correlates of open defecation in this region. A higher share of Muslims in the population positively correlated with lower open defecation rates, while this relationship was amplified by the population density. This finding support hypotheses about the positive sanitation externalities stemming from the spatial co-concentrations of Muslim and non-Muslim populations.

Conclusions: Our analyses demonstrate notable spatial clustering and significant spatial non-stationarity of the examined variables. Therefore, research findings that ignore the spatial heterogeneity of sanitation drivers possibly provide incomplete information for practice.

\section{Background}

The elimination of Open Defecation (OD) is a critical initial step towards ensuring safe sanitation, with this being a basic prerequisite for improving human health [1]. The eradication of this practice has been central to achieving the target of universal access to sanitation by 2030, as was declared under the sixth SDG (Sustainable Development Goal). However, while such SDGs and global efforts to ensure safe and hygienic sanitation has no doubt bettered conditions, it is unlikely that the above ambitious goal shall be achieved within the stipulated timeframe [2,3]. To stress the daunting task further, in 2017, OD was practiced by more than 673 million people worldwide, mostly in SubSaharan Africa and South Asia, with almost $50 \%$ of all such cases being from India alone [4].

Sanitation systems reveal especially high failure rates $[5,6,7,8]$ and sanitation interventions often lag behind initial policy expectations $[9,10,11]$. This is particularly true for past sanitation campaigns in India, such as the Central Rural Sanitation Programme (1986) or the Total Sanitation Campaign (1999-2012). The most recent endeavour, the Swachh Bharat Mission (2014-2019) (a restructured form of the Nirmal Bharat Abhiyan which ran from 2012-2014), has substantially increased toilet coverage across the country. However it remains to be seen whether this shall actually eliminate OD and foster sustainable sanitation changes, with toilet adoption still being far from universal [12, $13,14,15]$.

Possibly, the repeated failures or lowered effectiveness of past intervention policies have stemmed from sanitation practices being highly context sensitive and deeply embedded in human-environment interactions. Local sanitation conditions result from complex interactions between historically and culturally conditioned social behaviour, structural societal inequalities, multi-scalar sanitation politics and various natural environment parameters $[16,17$,

Loading [MathJax]/jax/output/CommonHTML/jax.js d even opposite effects on sanitation outcomes in different geographical 
settings and furthermore, the interrelationships between distinct sanitation drivers are also context sensitive $[19,20$, 10].

The implications of the contextual nature of sanitation have still to be fully understood. It makes the transferability of both, the policy interventions and any findings accrued from sanitation research, quite complex and difficult to generalize. Various measures have thus been recommended for adjusting the planned interventions to the targeted local environments $[21,22,7]$. This contextual sensitivity also amplifies an inverse relationship between the internal and external validity of garnered research findings. The experimental impact-evaluations represent an exemplar case in this respect. Although they attain high internal validity due to the effective elimination of contextual influences from the examined relationship between an intervention and its outcome, the methodological disregard of contextual factors means there is a weaker external validity (generalizability) of their results $[23,19,11]$. Contrarily, observational studies usually focus solely on statistical associations. As such, their internal validity is weaker. However, they can provide richer information on the roles of various observable contextual parameters and may also cover larger populations, which then adds to their external validity. On the other hand, inferences from larger-scale (i.e. ecological or population-level) studies are more susceptible to bias caused by various heterogeneities within the analyzed population. This challenges their ecological validity in terms of the extent to which such research results can be generalized to real-life settings [24].

The present article addresses the latter issue by examining how the inferences usually drawn about the correlates of OD practices in India are affected by heterogeneities demonstrated in space. More specifically, we focus on the problem of spatially varying relationships between OD and its covariates, which can be referred to as spatial nonstationarity or process spatial heterogeneity $[25,26]$. With this in mind, our paper has two goals. Firstly, to examine the district-level correlates of OD in India, and secondly, to assess the role of spatial heterogeneity in these correlates by comparing the results obtained using a standard non-spatial regression model with those obtained from spatially explicit regressions and a Multi-scale Geographically Weighted Regression (MGWR). Our analysis uses data from the Census of India (2011) covering a contiguous area of 266 districts (their rural parts) across seven northern and eastern states of India, wherein $65 \%$ of all households practicing OD across the country reside. Although at present, the 2011 Census data may be already somewhat outdated, the more recent data required for such district-level analysis of OD is not yet available. To the best of our knowledge, this paper presents the first spatially explicit analysis of district-level sanitation correlates in India as well as the first quantitative analysis of the spatial nonstationarity of sanitation determinants globally. This article thus seeks to make not only an empirical but also a methodological and epistemological contribution. It demonstrates an approach that can be adopted for a meso-scale analysis of sanitation drivers in India, as and when more recent district-level data is available. Moreover, despite the recent decline in OD in India, the prevalence of this practice is still likely to be substantial $[13,27]$ and possibly has a pronounced spatial variation. Therefore, the ascertained empirical evidence about the OD determinants in this study can still be valuable for addressing sanitation issues in India and other countries.

The variables used in the present study (which act as the correlates of OD) contain measures of the general socioeconomic situation of the studied districts, their occupational structure and their socio-ecological conditions. Additionally, we also examine the role of the proportion of Muslims in districts' population. Previous research has demonstrated that Muslim communities in India and elsewhere tend to have generally lower OD rates [28, 29, 30, 31]. In addition, Geruso and Spears (2018) [32] uncovered that, due to the comparatively better sanitation conditions of Muslim communities, the spatial co-concentrations of Muslim and non-Muslim neighbourhoods generate positive health externalities and decrease infant mortality rates in both Muslim and non-Muslim families. Inspired by this interesting finding, we have hypothesized that a greater proportion of Muslims in a district's population may not only Loading [MathJax]/jax/output/CommonHTML/jax.js ffect the sanitation conditions of non-Muslims. Since such externalities 
have a higher chance of arising in more densely populated areas [33], we expect that an area's population density shall moderate (amplify) the negative relationship between the share of Muslims and its prevalent OD rate.

Our results demonstrate that the parameters relating to the household ownership of assets, drinking water inaccessibility and literacy rate represent the most stable district-level correlates of the OD rate in India. Furthermore, our surmise about the negative association between the share of Muslim population and the district-level OD rates being contingent upon the level of population density was also confirmed. The latter finding supports our hypothesis about the positive sanitation effect of Muslim neighbourhoods and ultimately, the improved health externalities stemming from the spatial co-concentrations of Muslim and non-Muslim neighbourhoods. Overall, our analysis demonstrated a notable spatial clustering as well as a significant spatial non-stationarity of most of the examined variables. Therefore, studies that ignore the spatial heterogeneity of sanitation drivers possibly provide incomplete information, which may not be adequate for framing properly informed policies. While this claim of ours does have a general relevance with respect to most social and natural phenomena, we believe that sanitation represents a field in which geography matters particularly strongly.

\section{Complexity Of Sanitation Determinants}

The contextual nature of sanitation predetermines the complexity of its predictors. This also explains why the theoretical knowledge in this area only encompasses a few conceptual typologies of potentially important factors [34, $35,36,37,38]$, rather than being more causal theories. Conceptual typologies have to accommodate a large diversity of potential sanitation drivers operating on different scales. Some frequently represented types of factors that especially influence OD are demographic characteristics [39, 40], socio-economic and cultural attributes [41, 42, 30, $43,44]$ occupation $[37,45,17]$, dissatisfaction with sanitation infrastructure, in particular with poorly constructed government toilets $[46,40,47,48]$ and environmental and socio-spatial factors $(45,48,18,16,49]$.

A systematic review of the primary literature on rural community sanitation by Novotný et al. (2018) [19] identified 77 typological groups of sanitation drivers and 12 types of different sanitation outcomes. Drawing on the dataset that supplemented the systematic review referred to above, Fig. 1 illustrates the broader types of influencers of just two sanitation outcomes, in terms of OD, and the use of toilets, for select Asian and African countries. While there are some overarching types of factors similar to all these nations, it is notable that some of the drivers within these broader types may operate through distinct and contextually specific mechanisms. For example, findings from Benin and Bangladesh reveal that female-headed households are more likely to own toilets, while the evidence from Nigeria, Tanzania, Cambodia, and Nepal indicates an opposite relationship. In this case, the different socio-cultural and socioeconomic environments of female-headed households in these countries is the likely explanation [19].

\section{Note}

Based on supplementary information pertaining to Novotný et al. (2018a) [19].

The available sanitation research overwhelmingly comprises of case studies that most commonly draw on household-level micro-data. A few studies have investigated international and sub-national geographical inequalities in sanitation conditions $[50,51,52,53]$, while some have also analyzed the various sanitation determinants $[54,20$, 49]. The research focusing on the meso- and macro-level patterns of OD practices is generally scanty and rather descriptive, being often limited to simply monitoring basic sanitation indicators [55]. India is not an exception in this respect. We are aware of only two previous articles that have examined the district-level sanitation patterns in India $[56,42]$, even though these did not employ any spatially explicit analytical techniques. However, this does not imply 
that sanitation is ignored in ecological studies. Such research nevertheless more often employs sanitation indicators as covariates that explain the prevalent conditions of human health $[57,58,59]$, rather than directly examining them as outcomes.

\section{Data And Methods}

\subsection{Analyzed area}

The chosen study area is a contiguous region of 266 districts spread across seven northern and eastern states of India (Rajasthan, Uttar Pradesh, Madhya Pradesh, Chhattisgarh, Bihar, Jharkhand, Odisha and a small part of West Bengal) (Fig. 2). This region was demarcated by considering the spatial concentration of OD in India and within these districts lay $65 \%$ of all rural Indian households that practiced OD, as per the 2011 Census. In six of the above seven states, the respective state OD rates exceeded the national figure, with the sole exception being West Bengal (76\%). The eight districts from West Bengal were included in the studied region as they had disproportionately higher OD rates than the rest of the state and are socio-culturally and environmentally more similar to the neighbouring tracts of Jharkhand and Bihar than to the rest of West Bengal. The studied region has varied topography and land cover. As per the 2011 Census, it housed 494 million ruralites. It is socio-culturally diverse but socioeconomically less developed that the rest of India (e.g. literacy rate of 54\%), with Scheduled Castes and Scheduled Tribes comprising $18 \%$ and $16 \%$ of the total population, respectively.

\section{Note}

Only the chosen part of West Bengal in the study area is shown

Source: Census of India Atlas, 2011

\subsection{Methods}

The descriptive characteristics of the analyzed variables were enumerated first and their spatial patterns/clustering was examined using both, global and local indices of spatial association [60]. The Theil decomposition of spatial inequality [61] was used to ascertain what share of the overall between-district variations in particular variables was attributable to the differences between the respective state averages (between-state component) and to the differences between districts within respective states (within-state component). Next, the correlates of the district-level OD rate were examined using the following consecutive analytical steps to differentiate whether and how they addressed spatial heterogeneity and spatial non-stationarity (Table 1).

At first, we used a simple linear regression as a baseline model, which was characterized as:

$$
Y=\beta X+\epsilon
$$

where, $Y$ was the district-level OD rate, $X$ stood for the set of predictors described below, $\beta$ denoted the respective regression coefficients for these predictors and $\nabla$ was the error term. The intercept is not shown as we standardized all the variables analysed.

Linear regression assumes that the observations and error terms are mutually independent. However, in this case such an assumption may easily be violated by the spatial dependence in the data, e.g. by differences in sanitation interventions implemented in particular states or by any other state-level variations. Therefore, in the second step we 
additionally included dummy variables for particular Indian states among the independent variables, to control for any observable and unobservable differences between states (i.e. their fixed effects).

In the third and fourth steps, we attempted to better address the presence of spatial autocorrelation using two common alternatives of spatial regressions- the Spatial Lag model and the Spatial Error model [60]. The spatial lag regression presumes that the dependent variable in a district is not independent of its values in the neighbouring districts and was specified as:

$$
Y=\rho W Y+\beta X+\epsilon
$$

where, $\rho$ represented the spatial autoregressive lag coefficient and $W Y$ was a spatially lagged dependent variable. In the spatial error regression model, the assumption of spatially correlated errors was dealt with by including the spatial lag for errors. This was written as:

$Y=\beta X+\epsilon($ where, $\epsilon=\lambda W \epsilon+\mu)$

where, $\lambda$ was the spatial autoregressive error coefficient, $W \varepsilon$ denoted the spatial lag of errors and $\mu$ symbolised a random error term.

Although the above approaches deal with the various spatial heterogeneities in the data, they ignore spatial nonstationarity by assuming the stability of relationships between the independent variables and the dependent variable over space. In the fifth step, we explored this issue using MGWR $[62,63]$, which is a recent extension of the Geographically Weighted Regression (GWR) models $[64,65]$. Unlike methods that simply elicit global conditional relationships, the GWR models estimate local relationships by weighting observations based on the distance from a given district (i.e. by "borrowing" data from nearby units). The results of the local estimates are thus typically represented through maps. The MGWR additionally incorporates an assumption that the processes which determine the spatially varying regression parameters may operate at different spatial scales. It was expressed as:

$$
y_{i}=\sum_{j} \beta_{b w i j} X_{i j}+\epsilon_{i}
$$

where, $y_{i}$ was the dependent variable in a district $i, \beta_{i j}$ denoted the $j$-th local regression coefficient for the district $i$ and $b w j$ in $\beta_{b w i j}$ refers to the bandwidth used for the calculation of the regression estimates for the $j$-th predictor $x_{j}$ (i.e. the spatial range for 'borrowing' data from nearby units). This implies that the bandwidths may differ for particular conditional relationships and the optimal bandwidths were therefore determined by a consecutive fitting of models with different bandwidths and comparing their goodness-of-fit statistics. A back-fitting algorithm was also used for model calibration, as described in Fotheringham et al. (2017, p. 1249-1251) [62]. The adaptive bi-square spatial kernel that was applied as the weighting function was denoted as:

$w_{i j}=\left[1-\left(\frac{d_{i j}}{G_{i}}\right)^{2}\right]^{2}$ if $d_{i j}<g_{i}</>$ cript $>$ and zero otherwise

with $d_{i j}$ representing the distance between districts $i$ and $j$ and $G_{i}$ being the distance from district $i$ to its $N$-th nearest neighbour, as was determined again by an iterative comparison of the goodness-of-fit measures.

Although our district-level data was based on the 2011 Census and therefore may be considered as population data (in a statistical sense). we also rebort findings on the statistical significance of the results derived to provide an Loading [MathJax]/jax/output/CommonHTML/jax.js 
indication of the level of a given measure's effect that may simply occur by chance (e.g. due to random spatial distribution).

In addition to the regression analyses, we also applied cluster analysis in order to identify groups of districts with similar local effects of the analyzed predictors on the OD rate. A standard K-means clustering method was used for this purpose.

Table 1

Regressions used to model district-level OD rate and reflections of spatial heterogeneity and spatial non-stationarity

\begin{tabular}{|c|c|c|c|c|c|}
\hline Step & $\begin{array}{l}\text { Regression } \\
\text { model }\end{array}$ & $\begin{array}{l}\text { Assumption about spatial } \\
\text { heterogeneity }\end{array}$ & $\begin{array}{l}\text { Reflection of } \\
\text { spatial } \\
\text { heterogeneity }\end{array}$ & $\begin{array}{l}\text { Assumption } \\
\text { about spatial } \\
\text { non- } \\
\text { stationarity } \\
\text { (process } \\
\text { spatial } \\
\text { heterogeneity) }\end{array}$ & $\begin{array}{l}\text { Reflection of spatial } \\
\text { non-stationarity } \\
\text { (process spatial } \\
\text { heterogeneity) }\end{array}$ \\
\hline 1 & $\begin{array}{l}\text { Simple linear } \\
\text { regression }\end{array}$ & $\begin{array}{l}\text { Assumes both } \\
\text { observations and errors to } \\
\text { be spatially independent }\end{array}$ & None & \multirow{4}{*}{$\begin{array}{l}\text { Relationships } \\
\text { between } \\
\text { dependent } \\
\text { variable } \\
\text { assumed to } \\
\text { be stable } \\
\text { across space }\end{array}$} & \multirow[t]{4}{*}{$\begin{array}{l}\text { None, models global } \\
\text { average relationships }\end{array}$} \\
\hline 2 & $\begin{array}{l}\text { Linear } \\
\text { regression } \\
\text { with state } \\
\text { dummies }\end{array}$ & $\begin{array}{l}\text { Assumes the presence of } \\
\text { observable and } \\
\text { unobserved state-level } \\
\text { variations }\end{array}$ & $\begin{array}{l}\text { Dummy } \\
\text { variables for } \\
\text { states } \\
\text { considered } \\
\text { as covariates }\end{array}$ & & \\
\hline 3 & $\begin{array}{l}\text { Spatial lag } \\
\text { regression }\end{array}$ & $\begin{array}{l}\text { Dependent variable is } \\
\text { spatially autocorrelated; } \\
\text { dependent variable in a } \\
\text { focus district is related to } \\
\text { its level (and predictors) in } \\
\text { neighbouring districts }\end{array}$ & $\begin{array}{l}\text { Spatial lag of } \\
\text { dependent } \\
\text { variable } \\
\text { considered } \\
\text { as covariate }\end{array}$ & & \\
\hline 4 & $\begin{array}{l}\text { Spatial error } \\
\text { regression }\end{array}$ & $\begin{array}{l}\text { Error terms are assumed } \\
\text { to be spatially } \\
\text { autocorrelated due to } \\
\text { unobserved spatially } \\
\text { correlated covariates }\end{array}$ & $\begin{array}{l}\text { Spatial error } \\
\text { term } \\
\text { considered } \\
\text { as covariate }\end{array}$ & & \\
\hline 5 & $\begin{array}{l}\text { Multi-scale } \\
\text { Geographically } \\
\text { Weighted } \\
\text { Regression } \\
\text { (MGWR) }\end{array}$ & $\begin{array}{l}\text { Assumed to be inherent to } \\
\text { the analysed data }\end{array}$ & $\begin{array}{l}\text { Incorporates } \\
\text { spatial } \\
\text { dependency }\end{array}$ & $\begin{array}{l}\text { Relationships } \\
\text { between } \\
\text { dependent } \\
\text { variable and } \\
\text { predictors } \\
\text { assumed to } \\
\text { be spatially } \\
\text { varying }\end{array}$ & $\begin{array}{l}\text { Models local } \\
\text { relationships by } \\
\text { calculating separate } \\
\text { models for each } \\
\text { spatial unit (weighting } \\
\text { observations based on } \\
\text { distance from a focal } \\
\text { district) }\end{array}$ \\
\hline
\end{tabular}

Source: Prepared by the authors

\subsection{Variables}

The dependent variable was the district-wise percentage share of rural households that practiced OD, as was calculated from the Census of India, 2011 (Tables on Houses, Household Amenities and Assets). It was ascertained by considering the item 'no latrine within premises' but excluded those households that reported the use of public toilets. 
A set of 11 potentially relevant predictors was initially considered based on the same source of data- rural literacy rate, workforce participation rate in primary and non-primary activities, population density, share of Muslims in rural population, accessibility of drinking water source and five variables measuring the ownership of assets. For quantifying the primary sector workforce, cultivators and agricultural labourers were summed together, while the remaining categories of workforce were classified as the non-primary workforce. The population density (rural) was obtained by dividing the rural population of each district by that district's rural area (the total town area was subtracted from the total district area, as specified in the Town Amenities Table in the District Census Handbook).Water accessibility was measured as the share of households whose drinking water source was located away from the home premises (hereafter referred to as drinking water inaccessibility). The five variables measuring the ownership of assets included the shares of households owning a television, computer (with and without internet connections), mobile phone, scooters/motorcycles, and cars/jeeps/vans.

Due to multi-collinearity issues and a high internal consistency (the Cronbach's alpha of their standardized figures corresponded to 0.84), we decided to use a single composite index of the household assets owned in the ensuing analyses. This index was created via Principal Component Analysis. Here, the first component, which explained 65\% of variance and revealed the high loadings for the five variables of assets in the range 0.59 to 0.87 , was taken to represent the composite assets scores for particular districts.

Based on the inspection of multicollinearity, the variable denoting the primary sector workforce participation rate was excluded from the analyses. Although some of the other covariates were correlated (the highest correlation coefficient corresponded to 0.66 ), the appropriate diagnostics suggested an acceptable level of multi-collinearity among the six predictors that were eventually examined in the ensuing regression analyses. In addition to this, we also considered a two-way interaction between the share of Muslims and population density to test our hypothesis about the positive sanitation externalities arising due to the spatial co-concentration of Muslim and non-Muslim communities, as described in Sect. 2 above.

Before the regression analyses was undertaken, both the dependent and independent variables were z-standardised to enable comparisons of regression estimates across both variables and regression models. Such standardisation of variables is also recommended for the MGWR analysis [62].

\section{Results}

\subsection{Exploratory results}

Table 2 reports the descriptive characteristics for the analyzed variables, plus the global Moran's I measure of spatial autocorrelation and results of the Theil index of spatial inequality and its decomposition. To explore the more nuanced patterns of spatial clustering, Fig. 3 provides the maps of the local indices of spatial autocorrelation for all of the variables. Overall, these exploratory results clearly demonstrate that the examined variables are considerably spatially heterogeneous with non-trivial spatial patterns. The district-level OD rates ranged between $17 \%$ and $96 \%$, with a mean of $82 \%$ and the standard deviation being $12 \%$. In about $70 \%$ of the analyzed 266 districts, the OD rate was above $80 \%$, while there were only nine districts (two in Rajasthan and seven in Uttar Pradesh) where the share of OD practicing rural households was below $50 \%$. All of the measures showed significant (either high or very high) spatial autocorrelation. Although not negligible, the $\mathrm{OD}$ rate revealed a relatively lower spatial variation compared to the other variables, seemingly because we purposefully chose an area where the practice of OD was generally prevalent in 2011. Furthermore, the Theil index decomposition uncovered that the between-state component of spatial Loading [MathJax]/jax/output/CommonHTML/jax.js small share (2\%) of the overall spatial inequality. This share of between- 
state inequality is thus lower than that for other variables. In fact, it corresponds to what can be obtained based on a random spatial distribution (i.e. to the figure obtained by averaging results calculated from a repetitive random reallocation of the OD observations across the examined map of districts - see Novotný and Nosek, 2012 [66]. Rather surprisingly, it indicates that state boundaries are not crucial for delimiting/constraining the processes that influence the observed spatial variations in OD rates. This scenario is however quite different for some of the other examined variables, such as for the environmentally conditioned population density and access to drinking water source variables or for the share of Muslims in rural population variable, which are known to be spatially uneven due to socio-culturally conditioned settlement patterns.

Table 2

Descriptive characteristics and exploratory statistics for the examined variables (their original scales; $N=266$ districts)

\begin{tabular}{|c|c|c|c|c|c|c|c|}
\hline \multirow[t]{2}{*}{ Variable } & \multirow{2}{*}{$\begin{array}{l}\text { Mean } \\
(\%)\end{array}$} & \multirow{2}{*}{$\begin{array}{l}\text { Standard } \\
\text { deviation }\end{array}$} & \multirow[t]{2}{*}{ Min } & \multirow[t]{2}{*}{ Max } & \multirow{2}{*}{ Moran's } & \multicolumn{2}{|c|}{ Theil index } \\
\hline & & & & & & Overall & $\begin{array}{l}\text { Between-state } \\
\text { component (\%) }\end{array}$ \\
\hline $\begin{array}{l}\text { Share of households } \\
\text { practicing OD }\end{array}$ & 82 & 12 & 17 & 96 & 0.52 & 0.08 & 2 \\
\hline Literacy rate & 54 & 8 & 29 & 78 & 0.59 & 0.12 & 5 \\
\hline $\begin{array}{l}\text { Share of Muslims in } \\
\text { population }\end{array}$ & 10 & 12 & 0 & 70 & 0.72 & 0.54 & 45 \\
\hline $\begin{array}{l}\text { Non-primary work } \\
\text { participation rate }\end{array}$ & 9 & 4 & 4 & 21 & 0.52 & 0.14 & 15 \\
\hline Population density & 493 & 377 & 15 & 1632 & 0.80 & 0.21 & 66 \\
\hline $\begin{array}{l}\text { Drinking water } \\
\text { inaccessibility }\end{array}$ & 26 & 13 & 4 & 53 & 0.74 & 0.25 & 43 \\
\hline $\begin{array}{l}\text { Composite score of assets } \\
\text { ownership }\end{array}$ & 0 & 1 & -2 & 6 & 0.67 & - & - \\
\hline
\end{tabular}

Source: Computed by authors using Census of India 2011 information

Note: Rural population of the districts were used as the weights for calculating Theil index and its decomposition

\subsection{Regression analysis of global relationships}

Table 3 shows the results derived from the examination of the global relationships between the prevalent OD rate and its ascertained predictors. Although all four regression techniques proved to have relatively good explanative power, the spatial regressions performed notably better. Both the spatial lag $(\rho)$ and spatial error $(\lambda)$ coefficients were strong and statistically significant, confirming the importance of inculcating such spatial patterns of data in the modelling and gauging of the prevalence of OD practices. The best model fit was attained by the spatial error regression model and the appropriate diagnostics (robust Lagrange Multiplier statistics) indicated the superiority of this modelling approach with respect to our data. Comparisons of the two linear regression specifications revealed that the inclusion of the state-level dummy variables had led to only mild improvements in the goodness of fit. These state dummy variables were also not statistically significant. This finding corroborates the results obtained above by the Theil decomposition, implying the relative unimportance of state boundaries in explaining the spatial variation in the district-level OD rates prevalent in the examined area in 2011.

Loading [MathJax]/jax/output/CommonHTML/jax.js 
The relationships reported in Table 3 had the expected signs: the asset ownership, literacy rate, share of Muslims and non-primary work participation rate parameters were negatively associated with the OD rate, while the inaccessibility of drinking water revealed positive association. The composite index derived for assets owned, literacy rate and drinking water inaccessibility were identified as the significant predictors of the OD rate in all the four regression models. The population density was positively associated with OD in the linear and spatial lag regressions but this relationship disappeared in the spatial error regression. The non-primary work participation revealed a statistically significant effect in the spatial error regression. The proportion of Muslims in the rural population of a district was better associated with the OD rate in the linear regressions but weakly so in the spatial regression models, indicating that the effects of this variable may be spatially heterogeneous due to the above documented high spatial clustering of Muslims. The instability of regression parameters across individual regression models may be caused by the spatial non-stationarity of their relationships, which is further examined in Sect. 4.3.

The last model in Table 3 examined the interaction term between the share of Muslims and population density. Congruent to our hypothesis, a statistically significant negative joint effect of these two predictors on the OD rate was ascertained. This is an interesting finding, indicating that a concentration of Muslims in more densely inhabited areas possibly has some spill over effects, which positively affect sanitation conditions in these areas, not only in the Muslims neighbourhoods but also in the other communities situated adjacent/together with them. 
Table 3

Correlates of the OD rate- global regression relationships (standardised beta coefficients, standard errors)

\begin{tabular}{|c|c|c|c|c|c|}
\hline Covariates & $\begin{array}{l}\text { Simple } \\
\text { linear } \\
\text { regression }\end{array}$ & $\begin{array}{l}\text { Linear regression } \\
\text { with state } \\
\text { dummies }\end{array}$ & $\begin{array}{l}\text { Spatial } \\
\text { lag } \\
\text { regression }\end{array}$ & $\begin{array}{l}\text { Spatial } \\
\text { error } \\
\text { regression }\end{array}$ & $\begin{array}{l}\text { Spatial error regression } \\
\text { with interaction term }\end{array}$ \\
\hline Literacy rate & $\begin{array}{l}-0.151 \\
(0.045)^{\star \star}\end{array}$ & $-0.095(0.057)$ & $\begin{array}{l}-0.144 \\
(0.047)^{\star \star}\end{array}$ & $\begin{array}{l}-0.205 \\
(0.062) \star *\end{array}$ & $-0.211(0.060)^{\star \star}$ \\
\hline Share of Muslims & $\begin{array}{l}-0.170 \\
(0.074)^{\star}\end{array}$ & $-0.194(0.095) *$ & $\begin{array}{l}-0.088 \\
(0.050)\end{array}$ & $\begin{array}{l}-0.052 \\
(0.068)\end{array}$ & $0.112(0.081)$ \\
\hline $\begin{array}{l}\text { Non-primary work } \\
\text { participation rate }\end{array}$ & $\begin{array}{l}-0.110 \\
(0.074)\end{array}$ & $-0.145(0.080)$ & $\begin{array}{l}-0.111 \\
(0.050) *\end{array}$ & $\begin{array}{l}-0.146 \\
(0.060) *\end{array}$ & $-0.144(0.058)^{*}$ \\
\hline Population density & $\begin{array}{l}0.187 \\
(0.087) \star\end{array}$ & $0.210(0.086)$ * & $\begin{array}{l}0.127 \\
(0.057) *\end{array}$ & $\begin{array}{l}0.039 \\
(0.075)\end{array}$ & $0.034(0.074)$ \\
\hline $\begin{array}{l}\text { Drinking water } \\
\text { inaccessibility }\end{array}$ & $\begin{array}{l}0.411 \\
(0.108) \star \star\end{array}$ & $0.398(0.142)^{\star \star}$ & $\begin{array}{l}0.250 \\
(0.067)^{\star \star}\end{array}$ & $\begin{array}{l}0.144 \\
(0.072) *\end{array}$ & $0.126(0.070)$ \\
\hline $\begin{array}{l}\text { Score of assets } \\
\text { ownership }\end{array}$ & $\begin{array}{l}-0.309 \\
(0.060) \star \star\end{array}$ & $-0.419(0.080)^{\star \star}$ & $\begin{array}{l}-0.221 \\
(0.059) \star \star\end{array}$ & $\begin{array}{l}-0.461 \\
(0.077) \star \star\end{array}$ & $-0.482(0.076)^{\star \star}$ \\
\hline $\begin{array}{l}\text { West Bengal (8 } \\
\text { districts) }\end{array}$ & & $-0.497(0.360)$ & & & \\
\hline Odisha & & $-0.316(0.275)$ & & & \\
\hline Jharkhand & & $0.203(0.240)$ & & & \\
\hline Bihar & & $-0.369(0.369)$ & & & \\
\hline Chhattisgarh & & $-0.512(0.323)$ & & & \\
\hline Madhya Pradesh & & $-0.321(0.256)$ & & & \\
\hline Uttar Pradesh & & $0.034(0.318)$ & & & \\
\hline Rajasthan & & Reference cat. & & & \\
\hline $\begin{array}{l}\text { Spatial lag } \\
\text { coefficient }(\rho)\end{array}$ & & & $\begin{array}{l}0.512 \\
(0.061)^{\star \star}\end{array}$ & & \\
\hline $\begin{array}{l}\text { Spatial error } \\
\text { coefficient }(\lambda)\end{array}$ & & & & $\begin{array}{l}0.761 \\
(0.048) \star \star\end{array}$ & \\
\hline $\begin{array}{l}\text { Share of Muslims } \times \\
\text { Population density }\end{array}$ & & & & & $-0.189(0.056)^{\star \star}$ \\
\hline $\mathrm{R}^{2}$ & 0.432 & 0.468 & 0.561 & 0.653 & 0.671 \\
\hline Adjusted $\mathrm{R}^{2}$ & 0.419 & 0.440 & 0.549 & 0.644 & 0.661 \\
\hline $\mathrm{AIC}$ & 619 & 616 & 566 & 525 & 515 \\
\hline
\end{tabular}

\subsection{Examining local relationships}

With an $\mathrm{R}^{2}$ of 0.848 , adjusted $\mathrm{R}^{2}$ of 0.799 and $\mathrm{AIC}$ of 386 , the main-effects the MGWR model (i.e. without the Loading [MathJax]/jax/output/CommonHTML/jax.js obal regressions reported in Table 3. The summary results obtained for 
the individual covariates are presented in Table 4. It shows that the mean local beta coefficients for individual variables generally correspond to the regression parameters reported for the global regressions above. The strongest average local relationships with the OD rate was again revealed for the assets ownership score followed by the drinking water inaccessibility and literacy rate variables. The average local beta coefficients were closer to zero for the other variables and their standard deviations were higher. This suggests that their effects are either generally weaker or that they are spatially concentrated. The mean values of the local regression coefficients mask their considerable variability across the set of examined districts. Both the indices of variation of the local coefficients and the Monte Carlo spatial variability test documented that the relationships with the OD were significantly spatially unstable for all the predictors, except with the ownership of assets score. The spatial non-stationarity was particularly pronounced for the share of Muslims and population density, with $16 \%$ and $36 \%$, respectively, of the statistically significant local regression coefficients of these variables (and $45 \%$ and $33 \%$, respectively, of their all local coefficients) revealing opposite signs to those of their global beta coefficients. This seemingly implies that these variables may affect the OD rates through distinctly different mechanisms in different geographical regions. The interaction effect between this variable and the district-level population density may be one such mechanism.

Table 4

The summary results of the MGWR (main-effects model)

\begin{tabular}{|c|c|c|c|c|c|c|c|}
\hline Covariates & $\begin{array}{l}\text { Mean of } \\
\text { local beta } \\
\text { coefficients }\end{array}$ & $\begin{array}{l}\text { Standard } \\
\text { deviation } \\
\text { of local } \\
\text { beta } \\
\text { coefficients }\end{array}$ & $\begin{array}{l}\text { Local } \\
\text { beta } \\
\text { coefficient } \\
\text { - 1st } \\
\text { quartile }\end{array}$ & $\begin{array}{l}\text { Local } \\
\text { beta } \\
\text { coefficient } \\
\text { - 3rd } \\
\text { quartile }\end{array}$ & $\begin{array}{l}\text { Number of } \\
\text { districts } \\
\text { with } \\
\text { statistically } \\
\text { significant } \\
\text { local beta } \\
\text { coefficient } \\
(p<0.05)\end{array}$ & $\begin{array}{l}\text { Spatial } \\
\text { bandwidth } \\
\text { (number } \\
\text { of nearest } \\
\text { districts) }\end{array}$ & $\begin{array}{l}\text { Monte } \\
\text { Carlo test } \\
\text { for } \\
\text { spatial } \\
\text { variability } \\
\text { (p } \\
\text { values) }\end{array}$ \\
\hline Literacy rate & -0.212 & 0.109 & -0.307 & -0.114 & 114 & 65 & 0.002 \\
\hline $\begin{array}{l}\text { Share of } \\
\text { Muslims }\end{array}$ & -0.109 & 0.310 & -0.281 & -0.103 & 75 & 43 & 0.002 \\
\hline $\begin{array}{l}\text { Non-primary } \\
\text { work } \\
\text { participation }\end{array}$ & -0.103 & 0.210 & -0.241 & 0.057 & 58 & 43 & 0.020 \\
\hline $\begin{array}{l}\text { Population } \\
\text { density }\end{array}$ & 0.081 & 0.269 & -0.049 & 0.152 & 56 & 43 & 0.000 \\
\hline $\begin{array}{l}\text { Drinking } \\
\text { water } \\
\text { inaccessibility }\end{array}$ & 0.224 & 0.166 & 0.115 & 0.306 & 99 & 47 & 0.008 \\
\hline $\begin{array}{l}\text { Score of } \\
\text { assets } \\
\text { ownership }\end{array}$ & -0.277 & 0.124 & -0.329 & -0.246 & 153 & 62 & 0.316 \\
\hline
\end{tabular}

Figure 4: Spatial distribution of local beta coefficients obtained from the main MGWR model (isolines for $p$-values)

The local goodness of fit statistics (local $\mathrm{R}^{2}$ ) ranged between 0.36 to 0.92 with the distribution of its values tending towards the higher margin (local $\mathrm{R}^{2}$ values were above 0.80 for $78 \%$ of districts). As shown in Fig. 5 , districts with a low local goodness of fit were mostly concentrated in the eastern part of Uttar Pradesh. In addition to this, we inspected the spatial distribution of residuals obtained from the MGWR model and the Moran's I statistic of -0.035

Loading [MathJax]/jax/output/CommonHTML/jax.js 
The appropriate diagnostics did not suggest problems with collinearity in the global regressions and moreover, the mean values of the local collinearity measures were also below the recommended thresholds. More specifically, the mean local condition number was 20 and the mean local variance decomposition proportion (VDP) values for these particular predictors ranged between 0.14 and 0.38 . However, the inspection of these local collinearity measures indicated that collinearity may be an issue for some districts. Acknowledging that some of the predictors and their respective sets of local beta coefficients were significantly correlated, we investigated the sensitiveness of the results derived via the MGWR through alternative model specifications. For this, we ran six restricted MGWR models in which individual covariates were consecutively omitted (i.e. each of these restricted models had five independent variables instead of six, as in the full model above). The summary results obtained from this exercise appear in Table 5 . We found that the sets of local beta coefficients obtained in the full main-effect model above and from the restricted models are highly correlated (the fifth column in Table 5). Furthermore, the maps of the local regression coefficients averaged across the six restricted MGWR models (see Additional file fig. S-1) show very similar spatial patterns as that represented by the maps of the local coefficients obtained from the MGWR model (Fig. 4). Moreover, the other measures reported in Table 5 that characterize the regression results obtained from the restricted MGWR models, document their stability and do not challenge the inferences drawn from the MGWR model as reported above.

Table 5

The summary of results for restricted MGWR models

\begin{tabular}{|c|c|c|c|c|c|}
\hline Covariates & $\begin{array}{l}\text { Mean local } \\
\text { beta } \\
\text { coefficients } \\
\text { averaged } \\
\text { over six } \\
\text { restricted } \\
\text { models }\end{array}$ & $\begin{array}{l}\text { Minimum } \\
\text { mean local } \\
\text { beta } \\
\text { coefficient } \\
\text { (of six } \\
\text { restricted } \\
\text { models) }\end{array}$ & $\begin{array}{l}\text { Maximum } \\
\text { mean local } \\
\text { beta } \\
\text { coefficient } \\
\text { (of six } \\
\text { restricted } \\
\text { models) }\end{array}$ & $\begin{array}{l}\text { Correlation between full } \\
\text { model local beta } \\
\text { coefficients and } \\
\text { averaged local beta } \\
\text { coefficients over six } \\
\text { restricted model }\end{array}$ & $\begin{array}{l}\text { Number of districts } \\
\text { with significant } \\
\text { local beta } \\
\text { coefficients ( } p< \\
0.005 \text { ) in all six } \\
\text { restricted models }\end{array}$ \\
\hline Literacy rate & -0.229 & -0.307 & -0.182 & 0.984 & 73 \\
\hline $\begin{array}{l}\text { Share of } \\
\text { Muslims }\end{array}$ & -0.112 & -0.198 & -0.079 & 0.998 & 45 \\
\hline $\begin{array}{l}\text { Non-primary } \\
\text { work } \\
\text { participation }\end{array}$ & -0.112 & -0.192 & -0.066 & 0.998 & 45 \\
\hline $\begin{array}{l}\text { Population } \\
\text { density }\end{array}$ & 0.047 & -0.021 & 0.090 & 0.977 & 41 \\
\hline $\begin{array}{l}\text { Drinking } \\
\text { water } \\
\text { inaccessibility }\end{array}$ & 0.232 & 0.168 & 0.291 & 0.996 & 70 \\
\hline $\begin{array}{l}\text { Score of } \\
\text { assets } \\
\text { ownership }\end{array}$ & -0.343 & -0.414 & -0.254 & 0.987 & 112 \\
\hline \multicolumn{6}{|c|}{ Source: Computed and complied by the authors } \\
\hline
\end{tabular}

In the next step of our analysis we ran the MGWR model that additionally included the interaction term between the share of Muslims and population density. The summary results appear in Table 6 and show that the mean local regression coefficients for the interaction term corresponded to -0.146 , with the range between -0.279 and -0.081 and this was the lowest spatial variation from all analyzed predictors. The joint effect of the share of Muslims and Loading [MathJax]/jax/output/CommonHTML/jax.js ; thus seems to be quite stable spatially. However, the map of the local 
beta coefficients for the interaction term in Fig. 6.a indicates a clear west-east gradient, with the stronger and statistically significant effect localized in the western part of study area. Additionally, results revealed that the share of Muslim population (as a main-effect variable) of a district was also a statistically significant predictor of the OD rate in 110 districts. At the same time, in $94 \%$ of these districts, the local coefficients for the interaction term were also statistically significant. This implies that population density amplifies the effect of the share of Muslim population variable on OD rates.

Table 6

Summary of results for MGWR model with interaction between shares of Muslims and population density

\begin{tabular}{|c|c|c|c|c|c|c|}
\hline Covariates & $\begin{array}{l}\text { Mean of } \\
\text { local beta } \\
\text { coefficients }\end{array}$ & $\begin{array}{l}\text { Standard } \\
\text { deviation } \\
\text { of local } \\
\text { beta } \\
\text { coefficients }\end{array}$ & $\begin{array}{l}\text { Local } \\
\text { beta } \\
\text { coefficient } \\
-1 \text { st } \\
\text { quartile }\end{array}$ & $\begin{array}{l}\text { Local } \\
\text { beta } \\
\text { coefficient } \\
\text { - 3rd } \\
\text { quartile }\end{array}$ & $\begin{array}{l}\text { Number of } \\
\text { districts with } \\
\text { statistically } \\
\text { significant } \\
\text { local beta } \\
\text { coefficients (p } \\
<0.005 \text { ) }\end{array}$ & $\begin{array}{l}\text { Correlation between } \\
\text { sets of local beta } \\
\text { coefficients from } \\
\text { main-effects model } \\
\text { and model with } \\
\text { interaction term }\end{array}$ \\
\hline Literacy rate & -0.207 & 0.104 & -0.291 & -0.126 & 181 & 0.871 \\
\hline $\begin{array}{l}\text { Share of } \\
\text { Muslims }\end{array}$ & -0.090 & 0.138 & -0.242 & 0.044 & 110 & 0.777 \\
\hline $\begin{array}{l}\text { Non-primary } \\
\text { work } \\
\text { participation }\end{array}$ & -0.089 & 0.205 & -0.238 & 0.061 & 57 & 0.994 \\
\hline $\begin{array}{l}\text { Population } \\
\text { density }\end{array}$ & 0.026 & 0.239 & -0.124 & 0.121 & 42 & 0.976 \\
\hline $\begin{array}{l}\text { Drinking } \\
\text { water } \\
\text { inaccessibility }\end{array}$ & 0.222 & 0.195 & 0.096 & 0.293 & 93 & 0.978 \\
\hline $\begin{array}{l}\text { Score of } \\
\text { assets } \\
\text { ownership }\end{array}$ & -0.277 & 0.133 & -0.361 & -0.229 & 139 & 0.986 \\
\hline $\begin{array}{l}\text { Share of } \\
\text { Muslims x } \\
\text { Population } \\
\text { density }\end{array}$ & -0.146 & 0.068 & -0.217 & -0.086 & 112 & - \\
\hline
\end{tabular}

Source: Computed and complied by the authors

Finally, we tried to identify clusters of districts based on similarity in the local beta coefficients obtained in the previous step. For this purpose, we used a K-means method (applying the Euclidean distances and k-means ++ algorithm) with the final number of six clusters determined based on the consideration of changes in the sum of within-cluster squares. The final classification of districts appears in Fig. 6.b which shows that the resulting clusters are mostly spatially compact, and as such they may be thought of as distinct spatial regimes. Table 6 depicts the cluster centres for individual variables indicating how their relationships to the OD rate differ between these spatial entities. All of the analyzed predictors revealed comparatively strong effects within Cluster 5 (comprising 37 districts in western Uttar Pradesh, three districts in Northern Rajasthan and one district from northern Madhya Pradesh) and especially within Cluster 6 (consisting of eight districts in northern Rajasthan). The above is evidenced by drinking water inaccessibility and population density, with considerably stronger positive relationships to the OD rate in these clusters (and particularly in Cluster 6 ) than in the remaining zones. The interaction term between the share of Loading [MathJax]/jax/output/CommonHTML/jax.js :rong in these two clusters, in addition to Cluster 2 (most of Madhya 
Pradesh, remaining districts of Rajasthan and four districts from the south-west part of Uttar Pradesh). The role of the non-primary work participation parameter was found to be important for Clusters 5 and 6 and also for the other northern cluster (No. 4, comprising of 29 districts in eastern Uttar Pradesh, 11 districts from western Bihar and three districts from Madhya Pradesh). For Cluster 3 (made of 25 districts in eastern Bihar, 13 districts from Jharkhand, 6 from West Bengal and four from Madhya Pradesh), the literacy rate parameter appeared to be a relatively strong predictor. However, this Cluster 3, together with Cluster 1, represents groups with generally weaker local beta coefficients for all of the independent variables.

Table 7

Cluster centres for particular variables

\begin{tabular}{|lcccccc|}
\hline Indicator & Cluster 1 & Cluster 2 & Cluster 3 & Cluster 4 & Cluster 5 & Cluster 6 \\
\hline Literacy rate & -0.160 & -0.171 & -0.363 & -0.085 & -0.273 & -0.194 \\
\hline Share of Muslims & 0.044 & -0.210 & 0.033 & -0.058 & -0.277 & -0.270 \\
\hline Non-primary work participation & 0.046 & 0.060 & -0.032 & -0.353 & -0.282 & -0.291 \\
\hline Population density & -0.055 & 0.076 & -0.210 & 0.035 & 0.164 & 1.022 \\
\hline Drinking water inaccessibility & 0.160 & 0.189 & 0.160 & 0.043 & 0.520 & 0.774 \\
\hline Score of assets ownership & -0.270 & -0.412 & -0.228 & -0.062 & -0.344 & -0.401 \\
\hline Share of Muslims $\times$ Population density & -0.096 & -0.223 & -0.087 & -0.095 & -0.212 & -0.266 \\
\hline Source: Computed and compiled by the authors & & & & & \\
\hline
\end{tabular}

\section{Discussion}

The district-level variation in OD rates was relatively well-explained by the variations in the few predictors considered in this study. The $\mathrm{R}^{2}$ of the regression models ranged between 0.43 for the simple linear regression, 0.67 for the spatial error model and 0.85 for the MGWR. It suggests the importance of the population context for sanitation and endorses the value of the ecological studies conducted in this research domain, which have been dominated so far by a focus on micro-level evidence. Debates about the strengths and weaknesses of such ecological studies are often linked to the problems of ecological fallacy (false generalization of findings from the analysis of aggregated data to the individual level) and individualistic fallacy (disregard of population-level determinants when explaining individuallevel outcomes), thereby invoking a need to avoid them, for example, by using a multi-level analysis [67, 68]. A major practical issue, nevertheless, is that compatible individual-and population-level data are usually not available, as was the case in this study. Although weaker in terms of causal inference and limited in the range of available explanatory variables, population-level studies based on administrative data, remain a viable option for exploring larger-scale 'global' relationships, which are potentially more generalizable. However, using findings from ecological studies often means applying them at the local level within the population being examined. As our article has demonstrated, prior explorations of the stability of the identified global relationships becomes essential for this, particularly if the dependence of the analyzed phenomena on the variations in the external environment is high.

We have argued that sanitation represents an exemplary case in this respect. Each of the predictors examined in this study revealed statistically significant global relationship with the prevalent OD rate $(p<0.05)$ in at least two of the five global regression models, but only the assets ownership score was statistically significant in all of these rearescinns (Tahle 3) The variation in rearession parameters for the same predictors between different regression Loading [MathJax]/jax/output/CommonHTML/jax.js

Page $15 / 28$ 
models can largely be attributed to the presence of spatial autocorrelation in our data. Simple linear models did not account for such spatial dependence at all, implying that that the regression parameters may be inflated for most spatially autocorrelated covariates relative to those obtained from spatial regressions. This is exactly what we saw in Table 3 for the population density, inaccessibility of drinking water and the share of Muslims variables. These predictors revealed their strong spatial clustering (with the respective univariate Moran's I being $0.80,0.74$, and 0.72 ) and their beta coefficients thus became considerably lower in the spatial regression models when compared to those obtained from the simple linear model. As the data analyzed in this paper can be considered as population data (in a statistical sense), the regression parameters obtained by both the non-spatial and spatial models are valid. However, they have distinct interpretations and their relevance depends on judgements about the role of spatial clustering vis-àvis to analyzed global relationships. The results from the simple linear regression shows that the global relationships are relevant, if we believe that spatial autocorrelation represents a part of random disturbance. The spatial regressions provide additional information by indicating what the global relationships are if the effect of spatial clustering is controlled for.

Differences between the global regression coefficients obtained for the individual variables in the non-spatial and spatial regressions indicated the presence of spatially varying relationships that were explored in further detail using MGWR. While each of the predictors revealed statistically significant local relationships with the OD rate for at least 41 of the 266 districts, none of them were statistically significant in all the districts (Tables $4-6)$. The strengths of the local associations between each of the examined predictors and the OD rate were generally higher in the western part of the study area (region comprising of Rajasthan, western Uttar Pradesh and western Madhya Pradesh). The only exception was the literacy rate parameter, which displayed significant local effects in eastern Madhya Pradesh and in the north-eastern portion of the study area.

A more detailed look at the spatial variations in the local beta coefficients allowed us to identify six clusters of districts that had internally similar roles of the individual predictors of the OD rate (Fig. 6.b). Interestingly, these clusters often stretch across the state boundaries in our study area. Similarly, the decomposition of the Theil coefficient into the between-state and within-state components of district-level inequality (Table 2) as well as the inclusion of the state-level dummies into one of the global regression models (Table 3 ) showed that the state-level differences surprisingly explain only a small part of the district-level variations in the OD rate. This is a notable finding because state-level analysis is often the first option/method used when examining (or controlling for) spatial differences in India and it also represents a key policy framing level for the administration of sanitation interventions [13]. Our results, however, suggest that as far as sanitation issues go, the state as a unit does not represent the level at which the fundamental underlying processes related to this phenomenon operate. The differences in the spatial regimes of sanitation determinants discerned in this study (i.e. Figure 6.b) can be explored further and, possibly, considered for designing and administering suitable interventions.

Water availability is known to be a generally important barrier for toilet adoption in India and the same was confirmed in this study. However, the positive relationship between drinking water inaccessibility and the OD rate was considerably more pronounced in the north-western part of the study area, which is also comparatively more waterstressed [13]. The climatic conditions and associated spatial variations in the organisation of settlements may also be related to this positive relationship between the population density and the OD rate, as was identified for the same north-western part of Rajasthan. By contrast, the opposite. i.e. a negative association between population density and the $\mathrm{OD}$ rate was uncovered for the generally densely (and more evenly) populated north-eastern part of the study area (i.e. eastern Bihar, north-eastern portion of Jharkhand and the considered districts of West Bengal). These findings suggest that population density may operate through distinct mechanisms in location-specific different contexts.

Loading [MathJax]/jax/output/CommonHTML/jax.js

Page 16/28 
Moreover, population density was also shown to enhance (amplify) the negative association between the share of Muslims in the district population and the OD rate. This observation indicates that in addition to its direct effect (i.e. lower prevalence of OD among Muslims), a higher proportion of Muslims in the district population may additionally affect sanitation conditions indirectly through positive externalities stemming from the co-concentration of Muslims with non-Muslim (mostly Hindu) communities. Our study thus provides further support for a similar finding documented previously by Geruso and Spears (2018) [32]. However, our results differ from theirs in two respects. Firstly, Geruso and Spears (2018) [32] used village-level data (more specifically, the NFHS data at the level of its primary sampling units), while we have analyzed the information at the aggregated level of the districts. Secondly, they showed that the presence of Muslims in a locale generated positive health externalities for the neighbouring communities as well due to the better sanitation practices adopted by the Muslims neighbourhoods. Our results indicate that the sanitation conditions of the other communities are actually positively affected by their coconcentration with Muslims. As with the other statistical associations uncovered in this study, this result is only indicative. However, we regard this finding as quite an interesting topic for future research that can examine how the mechanisms underlying the nexus between the spatial concentrations of Muslims, sanitation conditions and health operate.

The assets ownership score and the literacy rate were identified as the two spatially most stable local correlates of OD in this study. These results signify the importance of wider socioeconomic development towards bettering sanitation conditions in India. This is a very basic and not a novel observation, but nevertheless is worth repeating, particularly in relation to the implementation of the Swachh Bharat Mission, which had aimed to make India OD free within a period of a few years. This finding implies that it is unlikely that this ambitious goal has been achieved or that the successes attained can be sustained only through specific sanitation interventions, unless the broader socioeconomic situation of rural communities is enhanced significantly $[29,69]$.

An obvious limitation of the present study is that it draws on the 2011 Census data, which may already be outdated. The National Family Health Survey (NFHS-4) from 2015-16 indicated a mild decline in the OD rate in the study area. However, the actual significant change in toilet coverage in this region probably occurred slightly after the NFHS-4 report was published, as a result of the implementation of the Swachh Bharat Mission. Recent data that records the effects of this intervention is not yet available and thus we could not undertake the related analyses in this paper. While the NFHS-4 data might be considered as an alternative information source, the district-level OD figures available from it are not reliable. Furthermore, as our analysis has demonstrated, studies conducted at the state level in India are not adequate for such spatial examinations of sanitation behaviour and its correlates. Even more importantly, we believe that our results are vital as they demonstrate the contextual nature of sanitation by documenting the considerable spatial heterogeneity and non-stationarity in the OD correlates. Therefore, our study has a general relevance and provides a model example for future research into similar topics, for example, when the 2021 Census data is published.

\section{Conclusion}

This article has analyzed the district-level correlates of open defecation in seven northern and eastern states of India that had reported comparatively high OD rates in 2011. Parameters like the ownership of assets, drinking water inaccessibility and the literacy rate were identified as the most stable correlates of the OD phenomenon. The representation of Muslims in the district population was negatively associated with its OD rate. Moreover, we showed that this effect is amplified by the level of population density, which indicates positive sanitation externalities due to that the spatial co-concentration of Muslim and non-Muslim populations. To our knowledge, this article provides the 
first quantitative analysis of spatial nonstationarity of sanitation determinants and clearly demonstrates that the spatial clustering and spatial nonstationarity of sanitation phenomena is substantial. As such, the findings derived from the various micro-level case studies that are usually undertaken should be generalized with much caution. There is a pertinent need to complement this evidence by population-level studies. Ecological studies should, however, focus on patterns by considering both the global relationships and their spatial heterogeneity. Research findings that ignore the spatial heterogeneity of sanitation drivers may possibly provide incomplete information for framing policies.

\section{Abbreviations}

AIC

Akaike Information Criterion; GWR:Geographically weighted regression; LISA:Local indicators of spatial autocorrelation; MGWR:Multiscale geographically weighted regression; OD:Open defecation.

\section{Declarations}

Ethics approval and consent to participate: Not applicable

Consent for publication: Not applicable

Availability of data and information: All the data used for this article are available in Census of India website. Competing interest: None.

Funding: None.

\section{Authors' Contribution:}

SC - Conceptualization, Methodology, Formal Analysis, Mapping and Visualization, Writing original draft, review and editing. JN - Conceptualization, Methodology, Formal Analysis, Mapping and Visualization, Writing original draft, review and editing. JD, AB, SR, SM, IM - Data Curation, manuscript revision, read and approved the submitted version. PPP - Demarcation of the analyzed area, editing, manuscript revision. SS, RB, AM, SP - manuscript revision, read and edits. All authors read and approved the final manuscript.

Acknowledgements: All authors gratefully acknowledge the Journal's support towards offering full waiver against APC. Saurav Chakraborty and Priyank Pravin Patel are thankful to Presidency University, Kolkata for all supports. Josef Novotný gratefully acknowledges support from the Czech Science Foundation [Grant number GA19-10396S]. Useful discussions with Avijit Mistri and Biswajit Mondal and support from Chandrima Paul are most appreciated and acknowledged. The authors are particularly thankful to Saswata Ghosh, Krishna Gopal Ghosh and Debarshi Guin for their support.

\section{References}

1. WHO. (2019). WHO global water, sanitation and hygiene: annual report 2018 (No. WHO/CED/PHE/WSH/19.147). World Health Organization.

2. Moyer JD, Hedden S. Are we on the right path to achieve the sustainable development goals?. World

Development. 2020 Mar 1;127:104749.

Loading [MathJax]/jax/output/CommonHTML/jax.js 
3. World Health Organization. Progress on household drinking water, sanitation and hygiene 2000-2017: special focus on inequalities. World Health Organization; 2019.

4. World Health Organization. Progress on drinking water, sanitation and hygiene: 2017 update and SDG baselines.

5. Starkl M, Brunner N, Stenstrom TA. Why do water and sanitation systems for the poor still fail? Policy analysis in economically advanced developing countries. Environ Sci Technol. 2013 Jun;18(12):6102-10. 47(.

6. Barnes R, Roser D, Brown P. Critical evaluation of planning frameworks for rural water and sanitation development projects. Development in Practice. 2011 Apr 1;21(2):168 - 89.

7. Davis A, Javernick-Will A, Cook SM. The use of qualitative comparative analysis to identify pathways to successful and failed sanitation systems. Science of The Total Environment. 2019 May 1;663:507 - 17.

8. Davis A, Javernick-Will A, Cook SM. Analyzing Sanitation Sustainability Assessment Frameworks for ResourceLimited Communities. Environmental science \& technology. 2019 Nov 1;53(22):13535-45.

9. Garn JV, Sclar GD, Freeman MC, Penakalapati G, Alexander KT, Brooks P, Rehfuess EA, Boisson S, Medlicott KO, Clasen TF. The impact of sanitation interventions on latrine coverage and latrine use: A systematic review and meta-analysis. International journal of hygiene and environmental health. 2017 Apr 1;220(2):329 - 40.

10. Cumming O, Arnold BF, Ban R, Clasen T, Mills JE, Freeman MC, Gordon B, Guiteras R, Howard G, Hunter PR, Johnston RB. The implications of three major new trials for the effect of water, sanitation and hygiene on childhood diarrhea and stunting: a consensus statement. BMC Med. 2019 Dec;17(1):1-9.

11. Whittington $D$, Radin $M$, Jeuland $M$. Evidence-based policy analysis? The strange case of the randomized controlled trials of community-led total sanitation. Oxf Rev Econ Policy. 2020 Jan;6(1):191-221. 36(.

12. Coffey D, Spears D. Implications of WASH benefits trials for water and sanitation. The Lancet Global Health. 2018 Jun 1;6(6):e615.

13. Exum NG, Gorin EM, Sadhu G, Khanna A, Schwab KJ. Evaluating the declarations of open defecation free status under the Swachh Bharat ('Clean India') Mission: repeated cross-sectional surveys in Rajasthan, India. BMJ Global Health. 2020 Mar 1;5(3):e002277.

14. Friedrich M, Balasundaram T, Muralidharan A, Raman VR, Mosler HJ. Increasing latrine use in rural Karnataka, India using the risks, attitudes, norms, abilities, and self-regulation approach: A cluster-randomized controlled trial. Science of The Total Environment. 2020 Mar;10:707:135366.

15. Verma R. Down to Earth report. 2019.

16. O'Reilly K, Louis E. The toilet tripod: Understanding successful sanitation in rural India. Health \& place. 2014 Sep $1 ; 29: 43-51$.

17. O'Reilly K, Dhanju R, Goel A. Exploring "the remote" and "the rural": Open defecation and latrine use in Uttarakhand, India. World Dev. 2017 May;1:93:193-205.

18. O'Reilly K. The influence of land use changes on open defecation in rural India. Appl Geogr. 2018 Oct;1:99:133-9.

19. Novotný J, Hasman J, Lepič M. Contextual factors and motivations affecting rural community sanitation in lowand middle-income countries: A systematic review. International journal of hygiene and environmental health. 2018 Mar 1;221(2):121 - 33.

20. Winter S, Dreibelbis R, Barchi F. Context matters: a multicountry analysis of individual-and neighbourhood-level factors associated with women's sanitation use in sub-Saharan Africa. Tropical Med Int Health. 2018 Feb;23(2):173-92.

21. Curtis V, Kanki B, Cousens S, Sanou A, Diallo I, Mertens T. Dirt and diarrhoea: formative research in hygiene promotion programmes. Health Policy and Planning. 1997 Jan 1;12(2):122 - 31.

Loading [MathJax]/jax/output/CommonHTML/jax.js

Page 19/28 
22. Wang S, Moss JR, Hiller JE. Applicability and transferability of interventions in evidence-based public health. Health promotion international. 2006 Mar 1;21(1):76-83.

23. Deaton A, Cartwright N. Understanding and misunderstanding randomized controlled trials. Social Science \& Medicine. 2018 Aug 1;210:2 - 1.

24. Lewkowicz DJ. The Concept of Ecological Validity: What Are Its Limitations and Is It Bad to Be Invalid? Infancy. 2001 Oct;2(4):437-50.

25. Fotheringham AS. The problem of spatial autocorrelation" and local spatial statistics. Geographical analysis. 2009 Oct;41(4):398-403.

26. Wolf LJ, Oshan TM, Fotheringham AS. Single and multiscale models of process spatial heterogeneity. Geographical Analysis. 2018 Jul;50(3):223-46.

27. Leong C. Narratives of sanitation: Motivating toilet use in India. Geoforum. 2020 May 1;111:24-38.

28. Banerjee AN, Banik N, Dalmia A. Demand for household sanitation in India using NFHS-3 data. Empirical Economics. 2017 Aug 1;53(1):307 - 27.

29. Coffey D, Gupta A, Hathi P, Spears D, Srivastav N, Vyas S. Understanding open defecation in rural India: Untouchability, pollution, and latrine pits. Economic and Political Weekly. 2017 Jan 7;52(1):59-66.

30. Novotný J, Ficek F, Hill JK, Kumar A. Social determinants of environmental health: a case of sanitation in rural Jharkhand. Science of The Total Environment. 2018 Dec 1;643:762 - 74.

31. Vyas S, Spears D. Sanitation and religion in South Asia: what accounts for differences across countries?. The journal of development studies. 2018 Nov 2;54(11):2119-35.

32. Geruso M, Spears D. Neighborhood sanitation and infant mortality. American Economic Journal: Applied Economics. 2018 Apr;10(2):125-62.

33. Hathi P, Haque S, Pant L, Coffey D, Spears D. Place and child health: the interaction of population density and sanitation in developing countries. The World Bank; 2014 Nov 1.

34. Jenkins MW, Curtis V. Achieving the 'good life': Why some people want latrines in rural Benin. Social science \& medicine. 2005 Dec 1;61(11):2446-59.

35. Devine J. Introducing SaniFOAM: a framework to analyze sanitation behaviors to design effective sanitation programs. Learning to Scale Up. Working Paper). Washington, DC. 2009 Oct.

36. Mosler HJ. A systematic approach to behavior change interventions for the water and sanitation sector in developing countries: a conceptual model, a review, and a guideline. International journal of environmental health research. 2012 Oct 1;22(5):431 - 49.

37. Dreibelbis R, Winch PJ, Leontsini E, Hulland KR, Ram PK, Unicomb L, Luby SP. The integrated behavioural model for water, sanitation, and hygiene: a systematic review of behavioural models and a framework for designing and evaluating behaviour change interventions in infrastructure-restricted settings. BMC public health. 2013 Dec 1;13(1):1015.

38. Jiménez A, LeDeunff H, Giné R, Sjödin J, Cronk R, Murad S, Takane M, Bartram J. The enabling environment for participation in water and sanitation: A conceptual framework. Water. 2019 Feb;11(2):308.

39. Coffey D, Gupta A, Hathi P, Khurana N, Spears D, Srivastav N, Vyas S. Revealed preference for open defecation. Economic Political Weekly. 2014 Sep;20(38):43. 49(.

40. Routray P, Schmidt WP, Boisson S, Clasen T, Jenkins MW. Socio-cultural and behavioural factors constraining latrine adoption in rural coastal Odisha: an exploratory qualitative study. BMC public health. 2015 Dec;15(1):880. 
41. Coffey D, Spears D, Vyas S. Switching to sanitation: understanding latrine adoption in a representative panel of rural Indian households. Soc Sci Med. 2017 Sep;1:188:41-50.

42. Ghosh A. Sanitation in West Bengal: Bangladesh shows the way. Economic Political Weekly. 2017;52(39):30-5.

43. Okurut K, Charles KJ. Household demand for sanitation improvements in low-income informal settlements: A case of East African cities. Habitat international. 2014 Oct 1;44:332-8.

44. Kunthy S, Catalla RN. Community-Led Total Sanitation (CLTS) in Cambodia. Final Evaluation. 2009 Jan.

45. Sara S, Graham J. Ending open defecation in rural Tanzania: which factors facilitate latrine adoption? Int J Environ Res Public Health. 2014 Sep;11(9):9854-70.

46. Banda K, Sarkar R, Gopal S, Govindarajan J, Harijan BB, Jeyakumar MB, Mitta P, Sadanala ME, Selwyn T, Suresh $\mathrm{CR}$, Thomas VA. Water handling, sanitation and defecation practices in rural southern India: a knowledge, attitudes and practices study. Transactions of the royal society of tropical medicine and hygiene. $2007 \mathrm{Nov}$ 1;101(11):1124-30.

47. Sinha A, Nagel CL, Schmidt WP, Torondel B, Boisson S, Routray P, Clasen TF. Assessing patterns and determinants of latrine use in rural settings: a longitudinal study in Odisha, India. International journal of hygiene and environmental health. 2017 Jul 1;220(5):906 - 15.

48. Abubakar IR. Exploring the determinants of open defecation in Nigeria using demographic and health survey data. Science of the total environment. 2018 Oct;1:637:1455-65.

49. Jain A, Fernald LC, Smith KR, Subramanian SV. Sanitation in Rural India: Exploring the Associations between Dwelling Space and Household Latrine Ownership. Int J Environ Res Public Health. 2019 Jan;16(5):734.

50. Galan DI, Kim SS, Graham JP. Exploring changes in open defecation prevalence in sub-Saharan Africa based on national level indices. BMC public health. 2013 Dec 1;13(1):527.

51. Pullan RL, Freeman MC, Gething PW, Brooker SJ. Geographical inequalities in use of improved drinking water supply and sanitation across sub-Saharan Africa: mapping and spatial analysis of cross-sectional survey data. PLoS medicine. 2014 Apr;11(4).

52. Dunn G, Johnson GD, Balk DL, Sembajwe G. Spatially varying relationships between risk factors and child diarrhea in West Africa, 2008-2013. Mathematical Population Studies. 2020 Jan;27(1)(2):8-33.

53. Apanga PA, Garn JV, Sakas Z, Freeman MC. Assessing the Impact and Equity of an Integrated Rural Sanitation Approach: A Longitudinal Evaluation in 11 Sub-Saharan Africa and Asian Countries. International Journal of Environmental Research Public Health. 2020 Jan;17(5):1808.

54. Luo Q, Zhang M, Yao W, Fu Y, Wei H, Tao Y, Liu J, Yao H. A spatio-temporal pattern and socio-economic factors analysis of improved sanitation in China, 2006-2015. Int J Environ Res Public Health. 2018 Nov;15(11):2510.

55. Fleming L, Anthonj C, Thakkar MB, Tikoisuva WM, Manga M, Howard G, Shields KF, Kelly E, Overmars M, Bartram J. Urban and rural sanitation in the Solomon Islands: How resilient are these to extreme weather events? Science of The Total Environment. 2019 Sep;15:683:331-40.

56. Ghosh A, Cairncross S. The uneven progress of sanitation in India. Journal of Water Sanitation Hygiene for Development. 2014 Mar;4(1):15-22.

57. Spears D, Ghosh A, Cumming O. Open defecation and childhood stunting in India: an ecological analysis of new data from 112 districts. PloS one. 2013;8(9).

58. Headey D, Hoddinott J, Ali D, Tesfaye R, Dereje M. The other Asian enigma: explaining the rapid reduction of undernutrition in Bangladesh. World Development. 2015 Feb 1;66:749 - 61.

59. Headey D, Palloni G. Water, sanitation, and child health: evidence from subnational panel data in 59 countries.

Loading [MathJax]/jax/output/CommonHTML/jax.js 2.

Page 21/28 
60. Anselin L, Syabri I, Kho Y. GeoDa: an introduction to spatial data analysis. InHandbook of applied spatial analysis 2010 (pp. 73-89). Springer, Berlin, Heidelberg.

61. Novotný J. On the measurement of regional inequality: does spatial dimension of income inequality matter?. The Annals of Regional Science. 2007 Sep 1;41(3):563 - 80.

62. Fotheringham AS, Yang W, Kang W. Multiscale geographically weighted regression (MGWR). Annals of the American Association of Geographers. 2017 Nov 2;107(6):1247-65.

63. Oshan TM, Li Z, Kang W, Wolf LJ, Fotheringham AS. mgwr: A Python implementation of multiscale geographically weighted regression for investigating process spatial heterogeneity and scale. ISPRS International Journal of Geo-Information. 2019 Jun;8(6):269.

64. Brunsdon C, Fotheringham AS, Charlton ME. Geographically weighted regression: a method for exploring spatial nonstationarity. Geographical analysis. 1996 Oct;28(4):281-98.

65. Fotheringham AS, Brunsdon C, Charlton M. Geographically weighted regression: the analysis of spatially varying relationships. John Wiley \& Sons; 2003 Feb 21.

66. Novotný J, Nosek V. Comparison of regional inequality in unemployment among four Central European countries: an inferential approach. Letters in Spatial and Resource Sciences. 2012 Jul 1;5(2):95-101.

67. Diez-Roux AV. Bringing context back into epidemiology: variables and fallacies in multilevel analysis. American journal of public health. 1998 Feb;88(2):216-22.

68. Loney T, Nagelkerke NJ. The individualistic fallacy, ecological studies and instrumental variables: a causal interpretation. Emerging themes in epidemiology. 2014 Dec;11(1):18.

69. Jain A, Wagner A, Snell-Rood C, Ray I. Understanding Open Defecation in the Age of Swachh Bharat Abhiyan: Agency, Accountability, and Anger in Rural Bihar. International journal of environmental research public health. 2020 Jan;17(4):1384.

\section{Figures}




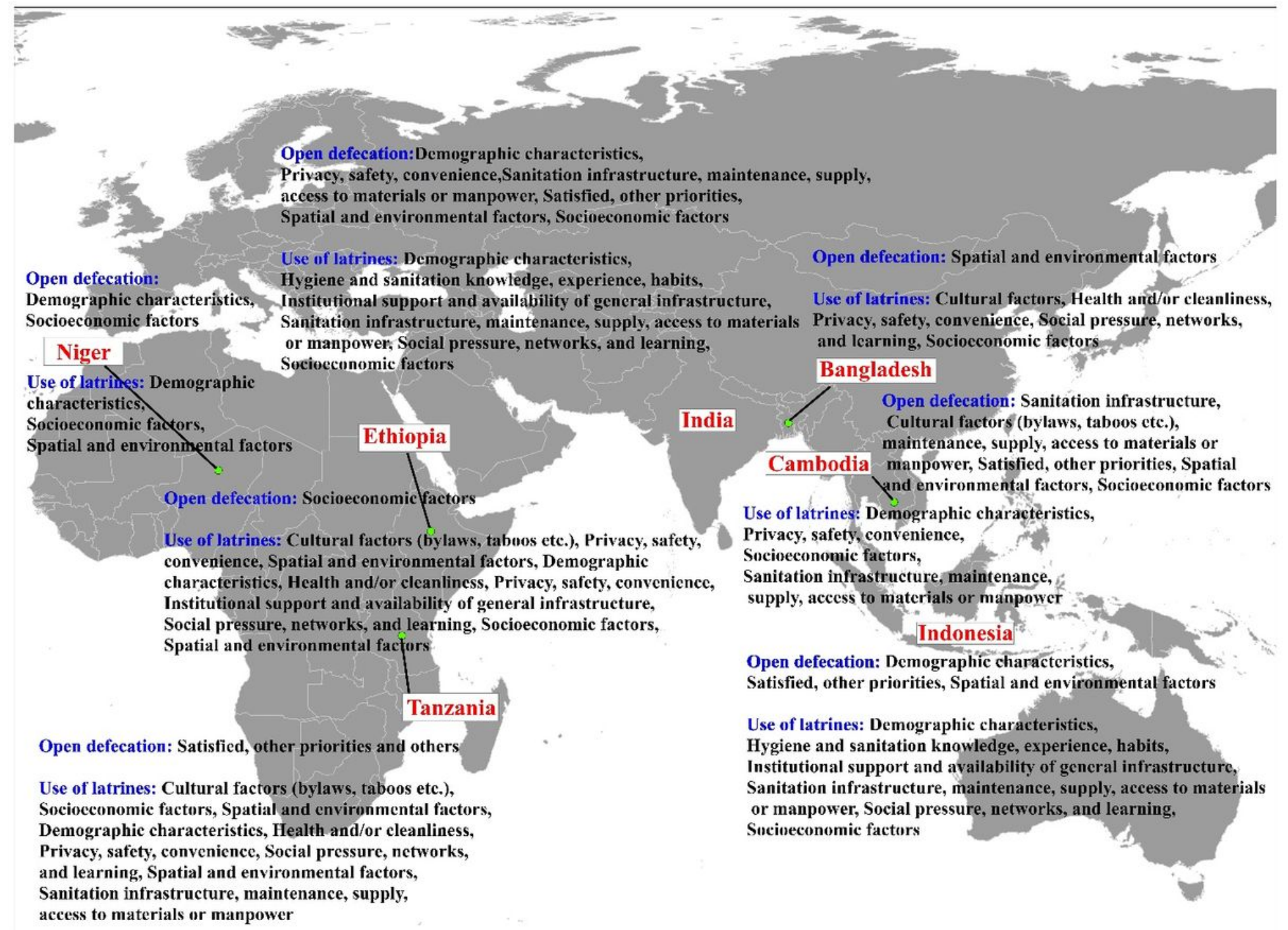

\section{Figure 1}

Broader types of correlates of OD and toilet use (for selected Asian and African countries). Note: The designations employed and the presentation of the material on this map do not imply the expression of any opinion whatsoever on the part of Research Square concerning the legal status of any country, territory, city or area or of its authorities, or concerning the delimitation of its frontiers or boundaries. This map has been provided by the authors. 


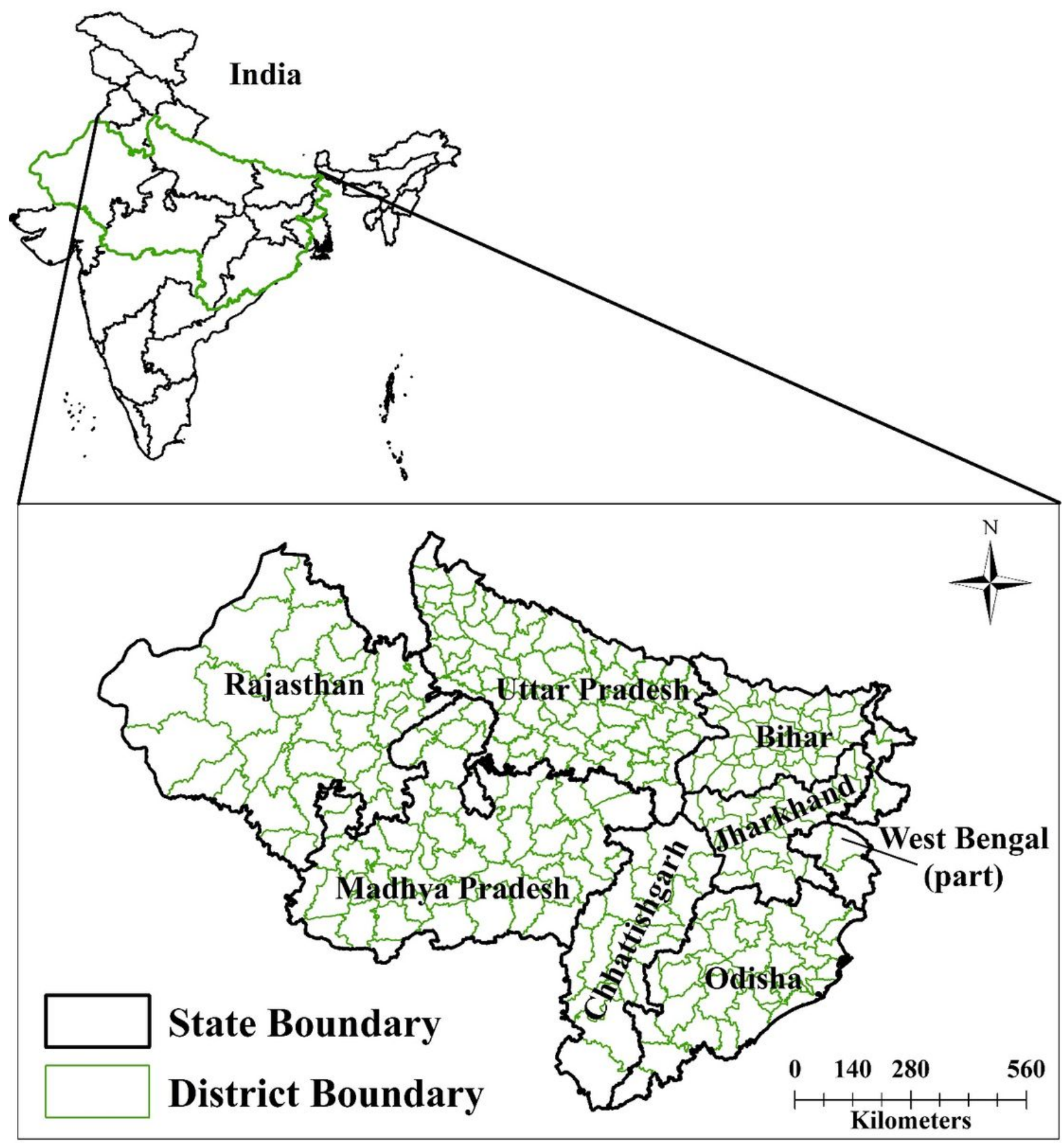

Figure 2

Study area with its administrative divisions 

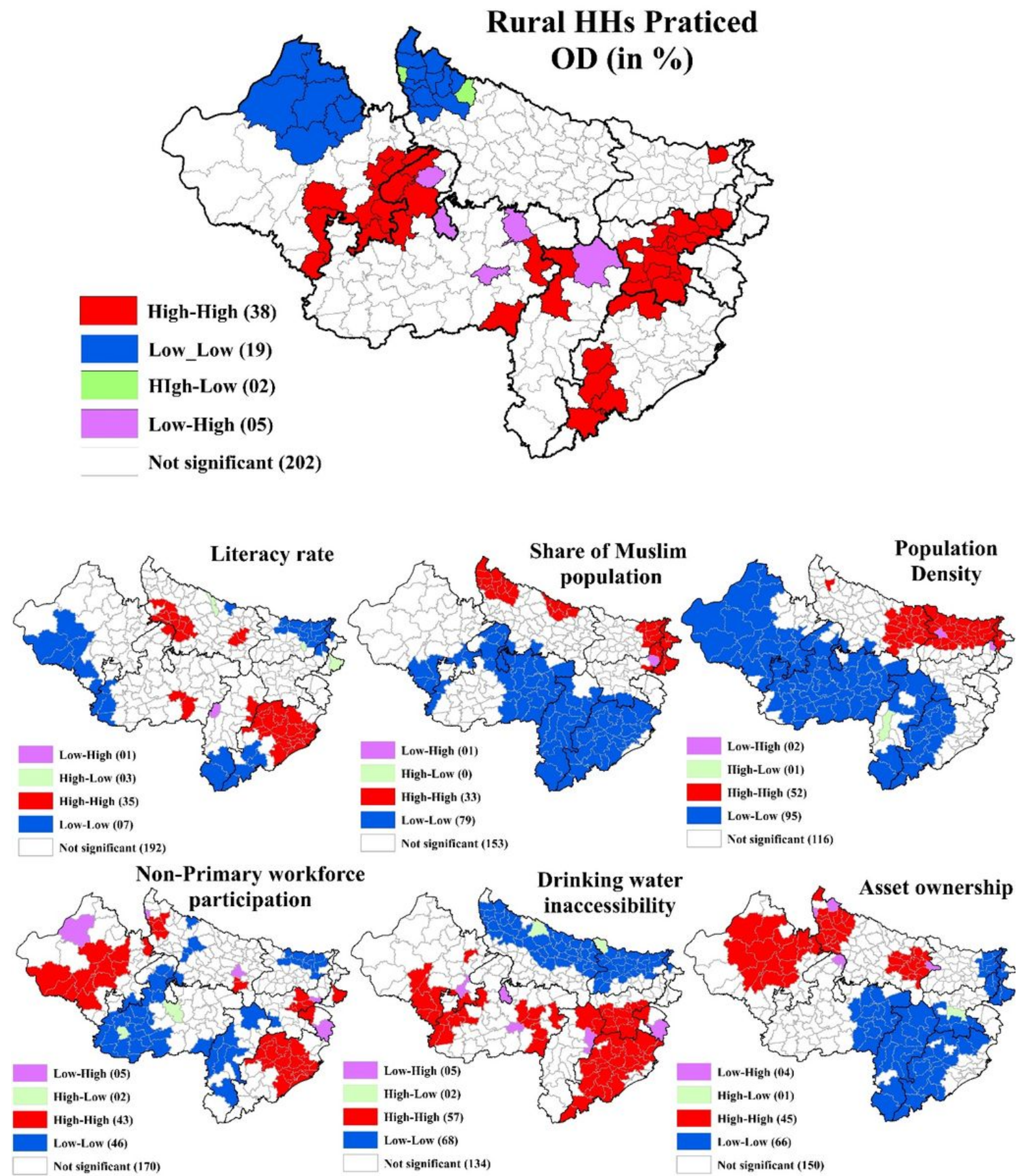

Figure 3

Maps of indices of LISA (local indicators spatial autocorrelation) for examined variables 

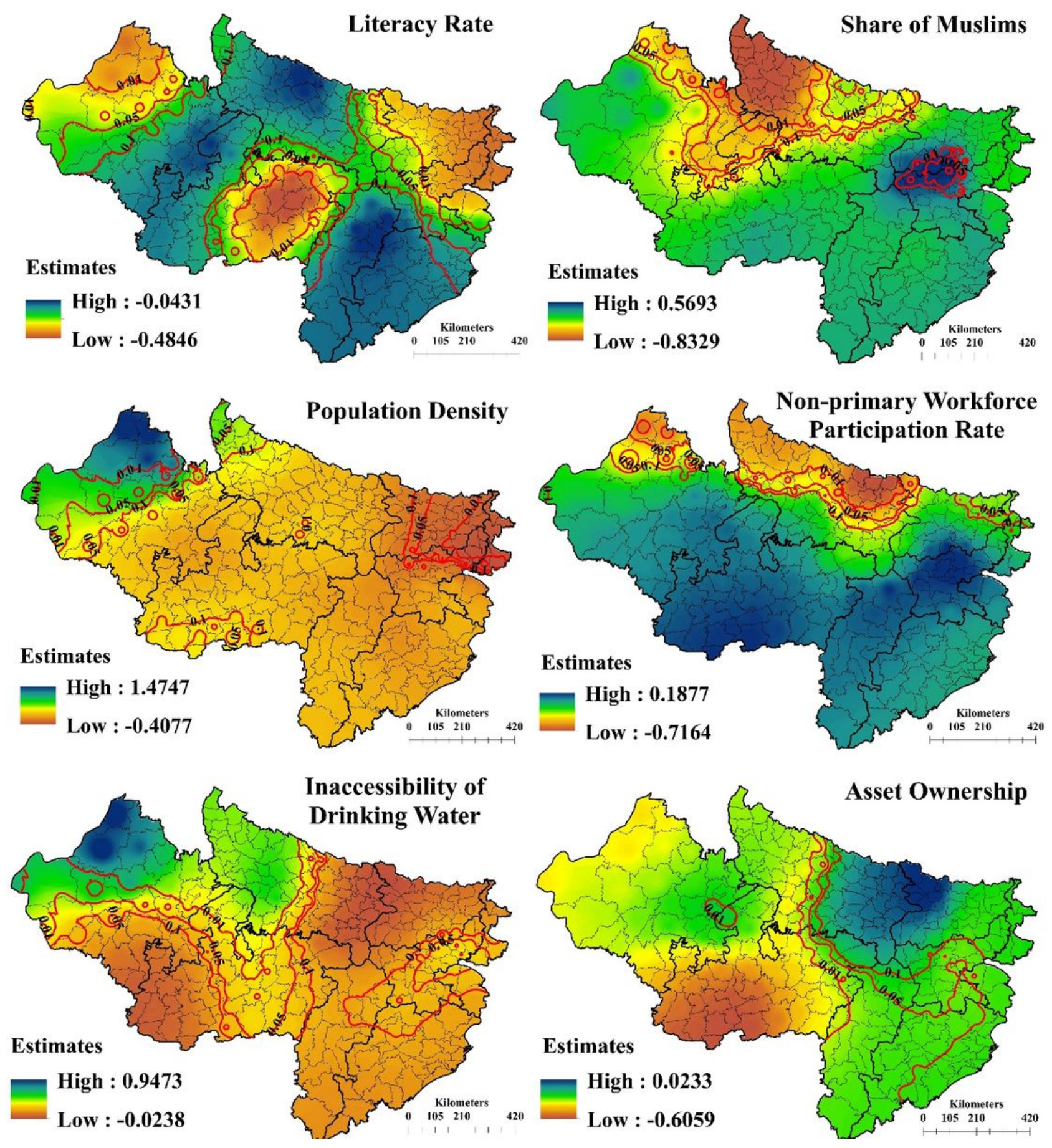

\section{Asset Ownership}

Figure 4

Spatial distribution of local beta coefficients obtained from the main MGWR model (isolines for p-values) 

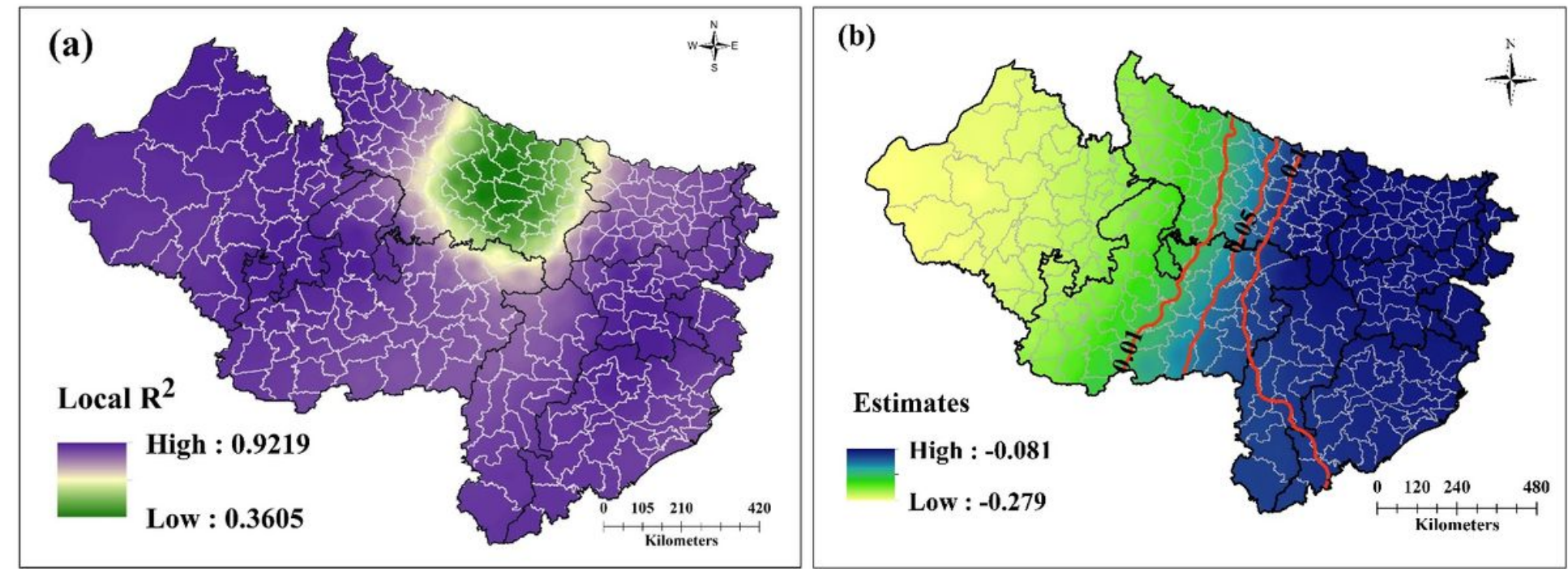

Figure 5

a. Spatial distribution of local R2 for the main MGWR model; b. Interaction term between the share of Muslims and population density (isolines for p-values)

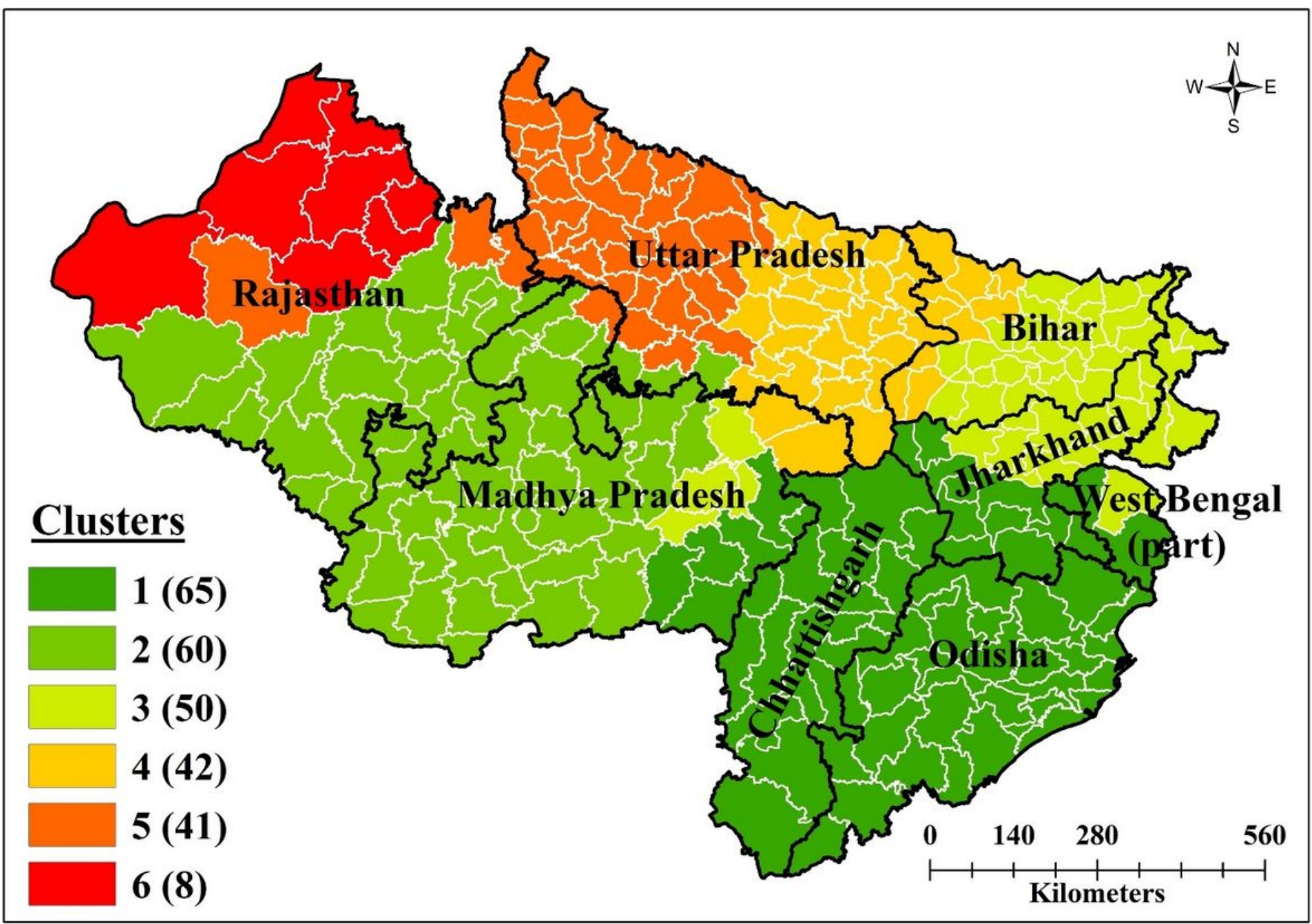

Figure 6 
Clusters of districts identified based on local beta coefficients (MGWR specification as in Table 6)

\section{Supplementary Files}

This is a list of supplementary files associated with this preprint. Click to download.

- coverletter.docx

- Supplementary.docx

Loading [MathJax]/jax/output/CommonHTML/jax.js 